\title{
Correlation of fatty acid composition of adipose tissue lipids and serum phosphatidylcholine and serum concentrations of micronutrients with disease duration in rheumatoid arthritis
}

\author{
L Jacobsson, F Lindgärde, R Manthorpe, B Åkesson
}

\begin{abstract}
To establish the concentrations of micronutrients in serum, fatty acid composition in serum phosphatidylcholine and in adipose tissue, and their correlation with inflammation and disease duration in rheumatoid arthritis (RA), 21 consecutive patients with recently diagnosed disease (mean duration eight months), 21 patients with longstanding disease (mean duration 15 years), and 57 controls were examined. In the patients with RA low concentrations of the essential fatty acids, linoleic acid (18:2) and linolenic (18:3) acid, and high concentrations of total saturated fatty acids, both in serum phosphatidylcholine and in adipose tissue, were found, abnormalities that increased with disease duration. The proportion of 18:2 in serum phosphatidylcholine correlated inversely with such acute phase proteins as orosomucoid and $\mathbf{C}$ reactive protein. It is proposed that the decreases in essential fatty acids are related to increased activity in the desaturase/elongation enzymes, increased production of eicosanoids, or metabolic changes secondary to cytokine mediated inflammatory reaction.

When the micronutrients were studied it was found that serum concentrations of selenium were lower in patients than in controls, but not those of ascorbic acid, $\alpha$ tocopherol, retinol, folic acid, or cobalamine. Ascorbic acid concentrations tended to be lower in RA, however, and correlated inversely with those of haptoglobin, orosomucoid, and C reactive protein, indicating a relation between the ascorbic acid concentration and the degree of inflammation.
\end{abstract}

The composition of fatty acids in plasma, cell membranes, and adipose tissue in different chronic diseases has recently become the focus of increasing interest. Altered patterns have been shown in coronary heart disease, ${ }^{1}$ for example, where it seems to be an independent risk factor for disease, in gout, ${ }^{2}$ and in such inflammatory connective tissue diseases as primary Sjögren's syndrome ${ }^{3}$ and juvenile chronic arthritis. ${ }^{4}$

There are several reasons for suspecting that fatty acid composition may be important in rheumatoid arthritis (RA). Firstly, increased amounts of eicosanoids are synthesised from C20 fatty acids ${ }^{5}$; secondly, acute inflammation induces alterations in fatty acid metabolism ${ }^{6}$; and, finally, administration of fish oil contain- ing eicosapentaenoic acid results in clinical improvement. ${ }^{7}$ It has been proposed that this last effect occurs because eicosapentaenoic acid leads to the formation of leucotrienes that are less inflammatory than those derived from arachidonic acid.

The aims of our study were to ascertain whether the proportions of essential fatty acids and micronutrients were changed in patients with RA, as compared with healthy subjects. Secondly, we wanted to establish whether any abnormalities found were early or late phenomena in the disease, by comparing results from patients who had had symptoms for less than one year with those from patients who had had RA for several years. Thirdly, we tried to evaluate whether the changes in fatty acid composition were present both in adipose tissue, reflecting the long term status of fatty acids, ${ }^{8-11}$ and in serum phosphatidylcholine, reflecting the short term status. Finally, we investigated the possibility of a correlation between the changes in fatty acid composition and micronutrients and clinical and paraclinical inflammatory variables.

\section{Patients and methods}

PATIENTS

Group A comprised 21 consecutive patients (14 women, seven men) with recently diagnosed RA (mean age 57 years, range 25-78) from the rheumatology section of the department of medicine. All patients had had symptoms for less than one year (mean eight months, range 4-11) and fulfilled the American Rheumatism Association criteria for definite or classical RA. ${ }^{12}$

Group B consisted of 21 patients with definite or classical RA of longer duration (mean 15 years, range 3-43), individually matched for sex and age with those in group A. All except two patients in groups $A$ and $B$ were receiving nonsteroidal anti-inflammatory drugs (NSAIDs) and 24/42 were receiving remission inducing drugs.

As a control group, 32 men and 25 women were selected from a health survey population. Their mean age was 57 years (range 50-70), and they had no rheumatic symptoms when examined.

COLLECTION OF BLOOD AND ADIPOSE TISSUE Blood was taken from an antecubital vein for counting of platelets and measurement of the 
following serum components: $\mathrm{C}$ reactive protein, haptoglobin, orosomucoid, cobalamine, selenium, retinol, $\alpha$-tocopherol, ascorbic acid, and cholesterol.

Fatty acid composition was analysed in serum phosphatidylcholine.

Adipose tissue was sampled from the outer quadrant of one of the buttocks using the Vacutainer technique. ${ }^{13}$ No local anaesthetic was given. The tissue sample was immediately frozen and stored in its original Vacutainer tubes at $-70^{\circ} \mathrm{C}$.

\section{ANALYSIS OF NUTRIENTS \\ Fatty acids}

Serum lipids were extracted and phosphatidylcholine was isolated by thin layer chromatography. ${ }^{4}$ Fatty acid methyl esters were prepared and separated by capillary gas chromatography using a $25 \mathrm{~m}$ column coated with SP 1000 and a temperature gradient of $200-240^{\circ} \mathrm{C} .{ }^{4}$ Data were expressed as percentages of major fatty acids. Adipose tissue biopsy specimens (less than 15 $\mathrm{mg}$ ) were treated with $2 \mathrm{ml}$ of $2 \%$ sulphuric acid in methanol:toluene $(1: 1)$ at $65^{\circ} \mathrm{C}$ for four hours. After the addition of $1 \mathrm{ml}$ water methyl

Table 1 Fatty acid composition of adipose tissue in healthy controls $(C)$ and patients with rheumatoid arthritis of short $(A)$ and longt $(B)$ duration. Data are expressed as means $(S D)$

\begin{tabular}{|c|c|c|c|}
\hline Fatty acid $\neq$ & $\begin{array}{l}\text { Group } A \\
(n=21)\end{array}$ & $\begin{array}{l}\text { Group } B \\
(n=20) S\end{array}$ & $\underset{(n=57)}{\text { Group }}$ C \\
\hline $\begin{array}{l}14: 0 \\
16: 0 \\
16: 1 \\
18: 0 \\
18: 1 \\
18: 2(n-6) \\
18: 3(n-3) \\
20: 1 \quad(n-1) \\
20: 4(n-6) \\
22: 5(n-3) \\
22: 6(n-3)\end{array}$ & $\begin{array}{c}3.84(0.81) \\
22.41(2.33) \\
6.53(1.18) \\
3.72(1.10) \\
45.79(2.28) \\
10.52(1.51)^{*} \\
0.60(0.12) \\
1.17(0.32) \\
0.24(0.07) \\
0.26(0.07) \\
0.35(0.13)\end{array}$ & $\begin{array}{c}3.92(0.86) \\
21.67(1.65) \\
7.53(1.92) \\
4.00(1.06) \\
45.51(1.87) \\
10.03(2.40)^{* *} \\
0.56(0.13)^{*} \\
1.12(0.26) \\
0.28(0.10) \\
0.27(0.09) \\
0.39(0.18)\end{array}$ & $\begin{array}{r}3.64(0.76) \\
21.70(2.11) \\
7.25(1.85) \\
3.78(0.95) \\
44.86(2.31) \\
12.13(3.05) \\
0.65(0.15) \\
1.07(0.28) \\
0.28(0.11) \\
0.31(0.16) \\
0.32(0.15)\end{array}$ \\
\hline $\begin{array}{l}\text { Total (n-6) } \\
\text { Total (n-3) } \\
\text { Total saturated }\end{array}$ & $\begin{array}{c}11.05(1.47)^{*} \\
1.19(0.26) \\
29.98(2.92)\end{array}$ & $\begin{array}{c}10.59(2.47)^{* *} \\
1.21(0.29) \\
29.59(2.92)\end{array}$ & $\begin{array}{r}12.72(3.06) \\
1.28(0.35) \\
29.12(3.07)\end{array}$ \\
\hline
\end{tabular}

${ }^{*} \mathrm{p}<0.05 ;{ }^{* *} \mathrm{p}<0.01 v$ healthy controls.

†Short=disease of less than one year (mean eight months); long=longstanding disease (mean 15 years).

$\ddagger$ Fatty acids are denoted by number of carbon atoms:number of double bonds.

†Fatty acids are denoted
fOne sample missing.

Table 2 Fatty acid composition of serum phosphatidylcholine in healthy controls $(C)$ and patients with rheumatoid arthritis of short $(A)$ and longt $(B)$ duration. Data are expressed as means $(S D)$

\begin{tabular}{|c|c|c|c|}
\hline Fatty acid $\neq$ & $\underset{(n=20)}{\text { Group } A}$ & $\begin{array}{l}\text { Group } B \\
(n=21)\end{array}$ & $\underset{(n=57)}{\text { Group }}$ C \\
\hline $\begin{array}{l}14: 0 \\
16: 0 \\
16: 1 \\
18: 0 \\
18: 1 \\
18: 2(n-6) \\
18: 3(n-3) \\
20: 3(n-6) \\
20: 4(n-6) \\
20: 5(n-3) \\
22: 5(n-3) \\
22: 6(n-3) \\
18: 2 / 20: 4\end{array}$ & $\begin{array}{c}0.51(0.13)^{* * *} \\
30.65(1.53)^{* *} \\
0.81(0.30)^{*} \\
13.59(1.12)^{*} \\
13.18(1.83)^{* *} \\
23.83(2.87) \\
0.29(0.10) \\
2.80(0.83) \\
7.16(0.83) \\
1.36(0.64)^{*} \\
0.92(0.22)^{*} \\
4.91(1.20) \\
3.39(0.66)\end{array}$ & $\begin{array}{c}0.36(0.11) \\
32.39(2.19)^{* * *} \\
0.69(0.19)^{* * *} \\
13.26(1.27)^{* *} \\
12.87(1.99)^{*} \\
21.84(2.23)^{* * *} \\
0.18(0.11)^{* * *} \\
2.58(0.47) \\
7.94(1.55) \\
2.05(1.36) \\
0.84(0.31)^{* *} \\
4.99(1.59) \\
2.89(0.79)^{* *}\end{array}$ & $\begin{array}{r}0.36(0.09) \\
29.34(1.77) \\
0.92(0.19) \\
14.12(1.10) \\
11.99(1.24) \\
24.78(2.44) \\
0.32(0.10) \\
2.69(0.66) \\
7.44(1.13) \\
1.83(0.85) \\
1.06(0.21) \\
5.16(1.08) \\
3.43(0.77)\end{array}$ \\
\hline $\begin{array}{l}\text { Total (n-6) } \\
\text { Total (n-3) } \\
\text { Total saturated }\end{array}$ & $\begin{array}{c}33.78(2.39)^{*} \\
7.48(1.81) \\
44.75(1.09)^{* *}\end{array}$ & $\begin{array}{l}32.36(1.62)^{* * *} \\
8.07(2.51) \\
46.02(1.54)^{* * *}\end{array}$ & $\begin{array}{r}35.06(2.38) \\
8.37(1.81) \\
43.82(1.31)\end{array}$ \\
\hline
\end{tabular}

${ }^{*} \mathrm{p}<0.05 ;{ }^{* *} \mathrm{p}<0.01 ;{ }^{* * *} \mathrm{p}<0.001 v$ healthy controls

+ Short $=$ disease of less than one year (mean eight months); long=longstanding disease (mean 15

$¥$ years).

SOne sample missing. esters were extracted twice with $1 \mathrm{ml}$ light petroleum and analysed by capillary gas chromatography.

\section{Micronutrients}

Selenium in serum was measured by graphite furnace atom absorption spectrometry with Zeeman background correction, using a ParkinElmer 3030 instrument. ${ }^{14}$ Retinol and $\alpha$ tocopherol were measured by high performance liquid chromatography, ${ }^{15}$ and ascorbic acid by spectrophotometry. ${ }^{16}$ Folate in blood, and serum concentrations of $\mathrm{C}$ reactive protein, haptoglobin, orosomucoid, cobalamine, and cholesterol were measured by standard methods used in the department of clinical chemistry at Malmö General Hospital.

Values for selenium in patients taking selenium supplements (one in group $A$ and two in group B) were excluded from the analysis.

\section{STATISTICAL ANALYSIS}

Student's two tailed $t$ test for unpaired samples was used for comparing healthy controls (C) with the two subgroups ( $A$ and $B$ ) of patients with RA. Spearman's @ was used to assess correlation. A $p$ value $\leqslant 0.05$ was considered significant.

\section{Results}

FATTY ACID COMPOSITION OF ADIPOSE TISSUE AND SERUM PHOSPHATIDYLCHOLINE IN RA

Patients with RA of long duration and short duration had decreased values for 18:2 and total n-6 acids, but normal values for the n-6 metabolites 20:3 and 20:4, both in adipose tissue (table 1) and serum phosphatidylcholine (table 2); the abnormalities increased with disease duration. Owing to the low values for linoleic acid, the ratio of 18:2 to 20:4 in serum was decreased as compared with controls, though the difference was significant only between controls and patients with disease of long duration.

For the n-3 series of fatty acids differences between groups were smaller and less consistent. Both in adipose tissue and serum phosphatidylcholine the proportion of 18:3 tended to decrease with increasing duration of disease (tables 1 and 2). Of the metabolites, the concentration of 22:5 was decreased in RA only in serum phosphatidylcholine (short duration RA, $\mathrm{p}<0.05$; long duration $\mathrm{RA}, \mathrm{p}<0.01$ ). The proportion of the major metabolite 22:6 did not differ significantly between any of the three groups.

In serum phosphatidylcholine, but not in adipose tissue, and as compared with controls, patients with RA also had increased values for 16:0 (short duration $\mathrm{RA}, \mathrm{p}<0.01$; long duration RA, $p<0.001$ ) and total saturated fatty acids (short duration RA, $\mathrm{p}<0.01$; long duration $\mathrm{RA}$, $p<0.001$ ), and decreased values for 16:1 (short duration $R A, p<0.05$; long duration $R A$, $p<0.001$ ) and 18:0 (short duration RA, $p<0.05$; long duration $\mathrm{RA}, \mathrm{p}<0.01$ ).

These changes also became more marked as disease duration increased. The abnormalities 
Table 3 Correlations between different serum acute phase proteins, platelet count, 18:2 in serum phosphatidylcholine and adipose tissue, and different micronutrients

\begin{tabular}{|c|c|c|c|c|c|}
\hline & Haptoglobin & Orosomucoid & $C R P t$ & Albumin & Platelets \\
\hline $\begin{array}{l}\text { Serum phosphatidylcholine } 18: 2 \\
\text { Adipose tissue } 18: 2 \\
\text { Serum selenium } \\
\text { Serum ascorbic acid } \\
\text { Serum } \alpha \text {-tocopherol } \\
\text { Serum retinol }\end{array}$ & $\begin{array}{l}-0.20 \\
-0.02 \\
-0.33^{*} \\
-0.64^{* * *} \\
-0.17 \\
-0.32^{*}\end{array}$ & $\begin{array}{l}-0.36^{* *} \\
0 \cdot 14 \\
-0 \cdot 49^{* *} \\
-0 \cdot 51^{* *} \\
0 \cdot 22^{*} \\
-0 \cdot 13\end{array}$ & $\begin{array}{l}-0.43^{* *} \\
0.04 \\
-0.18 \\
-0.51^{* *} \\
0.01 \\
-0.36^{* *}\end{array}$ & $\begin{array}{l}0.37^{* *} \\
-0.12 \\
0.16 \\
0.37^{* *} \\
-0.02 \\
0.24^{*}\end{array}$ & $\begin{array}{l}-0.26^{*} \\
-0.02 \\
-0.38^{* *} \\
-0.31^{*} \\
0.18 \\
-0.16\end{array}$ \\
\hline
\end{tabular}

${ }^{*} \mathrm{p}<0.05 ;{ }^{* *} \mathrm{p}<0.01 ;{ }^{* * *} \mathrm{p}<0.001$

tCRP $=\mathrm{C}$ reactive protein.

Table 4 Correlation coefficients (Spearman) and levels of significance between 18:2 in serum phosphatidylcholine and adipose tissue in controls and in subjects with rheumatoid arthritis (RA) of short and long duration

\begin{tabular}{llc}
\hline & $\begin{array}{l}\text { Correlation } \\
\text { coefficient }\end{array}$ & $p$ Value \\
\hline Controls & 0.50 & $<0.001$ \\
RA (short) & 0.43 & 0.015 \\
RA (long) & 0.02 & 0.23 \\
\hline
\end{tabular}

Table 5 Serum concentrations of different vitamins and selenium and blood folate in healthy controls and patients with rheumatoid arthritis of short and long duration. Values are expressed as means (SD)

\begin{tabular}{|c|c|c|c|}
\hline \multirow[t]{2}{*}{ Micronutrients } & \multirow{2}{*}{$\begin{array}{l}\text { Controls } \\
(n=57)\end{array}$} & \multicolumn{2}{|c|}{ Rheumatoid arthritis } \\
\hline & & $\begin{array}{l}\text { Short } \\
(n=20) S\end{array}$ & $\underset{(n=2 I)}{\text { Long }}$ \\
\hline $\begin{array}{l}\text { Selenium }(\mu \mathrm{mol} / \mathrm{l}) \\
\text { Retinol }(\mu \mathrm{mol} / /) \\
\alpha \text {-Tocopherol }(\mu \mathrm{mol} / \mathrm{l}) \\
\text { Ascorbic acid }(\mu \mathrm{mol} / \mathrm{l}) \\
\text { Cholesterol }(\mathrm{mmol} / \mathrm{l}) \\
\alpha \text {-Tocopherol/cholesterol }(\mu \mathrm{mol} / \mathrm{mmol}) \\
\text { Cobalamine }(\mathrm{pmol} / \mathrm{l}) \\
\text { Blood folate }(\mathrm{nmol} / \mathrm{l})\end{array}$ & $\begin{array}{l}1 \cdot 08(0 \cdot 17) \\
2 \cdot 7(0 \cdot 5) \\
32 \cdot 4(7 \cdot 9) \\
43(25) \\
5 \cdot 9(1 \cdot 0) \dagger \\
5 \cdot 6(1 \cdot 4) \dagger \\
270(142) \dagger \\
277(82) \dagger\end{array}$ & $\begin{array}{l}0 \cdot 98(0 \cdot 19)^{*} \ddagger \\
2 \cdot 8(0 \cdot 7) \\
31 \cdot 5(8 \cdot 7) \\
31(17) \\
5 \cdot 5(1 \cdot 2)^{*} \\
5 \cdot 9(1 \cdot 6) \\
239(97) \\
332(132)\end{array}$ & $\begin{array}{l}0 \cdot 96(0 \cdot 21)^{* *} \ddagger \\
2 \cdot 5(0 \cdot 9) \\
30 \cdot 0(9 \cdot 3) \\
31(22) \\
5 \cdot 3(1 \cdot 1)^{* *} \\
5 \cdot 8(1 \cdot 6) \\
331(161) \\
352(241)\end{array}$ \\
\hline
\end{tabular}

${ }^{*} \mathrm{p}<0.05 ;{ }^{* *} \mathrm{p}<0.01 v$ controls.

tn $=55$.

$\neq n=19$.

SOne sample missing.

Table 6 Fatty acid composition of adipose tissue in healthy controls and patients with rheumatoid arthritis, by sexes. Data are expressed as means (SD)

\begin{tabular}{|c|c|c|c|c|}
\hline \multirow[t]{2}{*}{ Fatty acidt } & \multicolumn{2}{|l|}{ Controls $(n=57)$} & \multicolumn{2}{|c|}{ Rheumatoid arthritis $(n=28)$} \\
\hline & $\underset{(n=32)}{M e n}$ & $\begin{array}{l}\text { Women } \\
(n=25)\end{array}$ & $\begin{array}{l}\text { Men } \\
(n=13)\end{array}$ & $\begin{array}{l}\text { Women } \\
(n=28)\end{array}$ \\
\hline $\begin{array}{l}14: 0 \\
14: 1 \\
16: 0 \\
16: 1 \\
18: 0 \\
18: 1 \\
18: 2(n-6) \\
18: 3(n-3) \\
20: 1 \\
20: 4(n-6) \\
22: 5(n-3) \\
22: 6(n-3)\end{array}$ & $\begin{array}{c}3.73(0.79) \\
0.52(0.21) \\
22.82(1.67)^{* * *} \\
6.62(1.80)^{* * *} \\
4.03(1.03)^{*} \\
44.32(2.25) \\
11.67(2.17) \\
0.67(0.14) \\
1.11(0.29) \\
0.28(0.11) \\
0.34(0.18) \\
0.32(0.17)\end{array}$ & $\begin{array}{r}3.52(0.72) \\
0.58(0.19) \\
20.28(1.75) \\
8.05(1.60) \\
3.46(0.75) \\
45.56(2.23) \\
12.73(3.86) \\
0.63(0.16) \\
1.02(0.26) \\
0.27(0.12) \\
0.28(0.14) \\
0.31(0.13)\end{array}$ & $\begin{array}{c}4.04(0.82) \\
0.52(0.15) \\
22.23(2.22)^{* *} \\
6.53(1.63) \\
4.01(0.98) \\
45.02(2.07) \\
10.00(2.39) \\
0.56(0.17) \\
1.10(0.28) \\
0.22(0.05) \\
0.24(0.05) \\
0.42(0.13)\end{array}$ & $\begin{array}{r}3.80(0.83) \\
0.50(0.16) \\
21.50(1.73) \\
7.24(1.63) \\
3.79(1.13) \\
45.95(2.04) \\
10.41(1.80) \\
0.59(0.11) \\
1.17(0.29) \\
0.28(0.09) \\
0.27(0.09) \\
0.34(0.16)\end{array}$ \\
\hline $\begin{array}{l}\text { Total (n-6) } \\
\text { Total (n-3) } \\
\text { Total saturated }\end{array}$ & $\begin{array}{l}12.26(2 \cdot 19) \\
1.32(0.39) \\
30.57(2 \cdot 72)^{* * *}\end{array}$ & $\begin{array}{r}13 \cdot 25(3 \cdot 80) \\
1.22(0 \cdot 29) \\
27 \cdot 26(2 \cdot 44)\end{array}$ & $\begin{array}{c}10.49(2.40) \\
1.19(0.30) \\
31.28(2.69)^{*}\end{array}$ & $\begin{array}{r}10.98(1.83) \\
1.21(0.27) \\
29.10(2.76)\end{array}$ \\
\hline
\end{tabular}

${ }^{*} \mathrm{p}<0.05 ;{ }^{* *} \mathrm{p}<0.01 ;{ }^{* * *} \mathrm{p}<0.001 v$ women

tFatty acids are denoted by number of carbon atoms: number of double bonds.

in fatty acid composition were present both in male and female patients. No differences in fatty acid composition were observed between patients with more marked clinical symptoms (morning stiffness $>2$ hours or Ritchie index $>8$, or both $(n=15))$ and those with less active disease. Among patients with RA, however, there were significant negative correlations between 18:2 in serum phosphatidylcholine and such acute phase proteins as orosomucoid $(\mathrm{r}=-0.36, \mathrm{p}=0.008)$ and $\mathrm{C}$ reactive protein $(r=-0.43, p=0.002)$ (table 3$)$. No such correlations were observed, however, between acute phase proteins and 18:2 in adipose tissue; this is in accord with the decrease in correlation between 18:2 in serum phosphatidylcholine and adipose tissue with increasing disease duration, the correlation coefficient varying from 0.50 $(p<0.001)$ in controls to $0.43(p=0.015)$ in $R A$ of short duration and to $0.02(p=0.23)$ in RA of long duration (table 4).

\section{MICRONUTRIENTS}

Of the micronutrients analysed (table 5), low serum concentrations were observed in the arthritis group for selenium, but normal values for blood folate, and serum concentrations of retinol, $\alpha$-tocopherol, ascorbic acid, and cobalamine, though ascorbic acid concentrations tended to be lower in patients. The $\alpha$-tocopherol/ cholesterol ratio in serum did not differ significantly between controls, and either newly diagnosed or longstanding RA (table 5).

Despite the absence of significantly decreased serum values of micronutrients other than selenium in the subjects with RA, there were some correlations between selenium, ascorbic acid and retinol, and acute phase reactants. Ascorbic acid in particular correlated inversely with haptoglobin $(r=-0.64, p<0.001)$, orosomucoid $(r=-0.51, p=0.002)$, and $C$ reactive protein $(r=-0.51, p=0.002)($ table 3$)$.

\section{FATTY ACID COMPOSITION OF ADIPOSE TISSUE IN} MEN AND WOMEN

Both in controls and patients the proportion of total saturated fatty acids in adipose tissue, particularly that of 16:0, was higher among men than among women $(p<0.001)$ (table 6). Women instead had somewhat higher values for mono-unsaturated and di-unsaturated fatty acids such as 16:1 ( $\mathrm{p}<0.01), 18: 1$, and 18:2. The differences according to sex were about the same both in controls and patients. For polyunsaturated fatty acids with more than two double bonds values were essentially the same for men and women. In serum phosphatidylcholine there were no differences dependent on sex in the concentrations either of saturated or unsaturated fatty acids.

The slight differences according to sex for 18:2 indicate that the decrease of this essential fatty acid found among patients is even larger if correction is made for group differences in sex distribution, as the proportion of women was higher in the patient groups (A and B). 


\section{Discussion}

In the patients with arthritis we found similar alterations both in serum phosphatidylcholine and adipose tissue, with low values for 18:2, $18: 3$, and total n-6 fatty acids, and no compensatory increase in other polyunsaturated fatty acids, but a comparative increase in saturated fatty acids. Similar disturbances in the n-6 series of fatty acids in RA have previously been found in serum phospholipids ${ }^{17}$ and in serum free fatty acids, ${ }^{18}$ though the composition of fatty acids in adipose tissue was not measured in either of these studies.

Possibly, the low proportions of 18:2 and 18:3 in serum phosphatidylcholine and adipose tissue among patients with $\mathrm{RA}$ are to be explained by a lower intake of these fatty acids, though this notion derives no support from the findings of any of the few available studies of adult and juvenile patients. ${ }^{19} 20$ Moreover, in view of the fact that the abnormalities increased with disease duration and correlated partly with the acute phase protein response it is reasonable to assume that they are related to the degree of inflammation and not to dietary habits.

A second possible mechanism responsible for the changes in fatty acid composition might be an increase or imbalance in the synthesis of eicosanoids from $20-22$ carbon fatty acids. ${ }^{5}$ Were this the case, however, low values would be expected for the 20-22 carbon fatty acids and we obtained no such low values. That no low values were found for prostaglandin precursors is perhaps to be explained by the fact that practically all our patients were receiving NSAIDS, as intake of these drugs has been reported to normalise low plasma values of unesterified 20:4 in patients with RA. ${ }^{21}$

Possibly also, the low 18:2/20:4 ratio in RA may be explained by an increase in fatty acid desaturation/elongation. One possible mediator of such an effect is insulin, which stimulates desaturation $^{22}$ and has been found at high concentrations in patients with RA. ${ }^{23}$ Data on the enzyme activities occurring in fatty acid interconversion are needed for an evaluation of this hypothesis.

It is noteworthy that the correlation between 18:2 in serum phosphatidylcholine and in adipose tissue was poorer in patients, especially in those with long disease duration, than in controls. In addition, only 18:2 in serum phosphatidylcholine correlated with biochemical indicators of disease activity (table 3). This correlation might simply be due to the greater similarity in turnover cycles of serum phosphatidylcholine 18:2 (weeks) and acute phase reactants (days-weeks), as compared with adipose tissue 18:2 (years). The possibility that different mechanisms are responsible for the abnormalities in serum phosphatidylcholine 18:2 and adipose tissue 18:2 cannot be ruled out, however.

It is tempting to speculate that the decrease in serum phosphatidylcholine $18: 2$ constitutes part of the inflammatory response, mediated by cytokines, the concentrations of which are known to be increased in patients with RA. ${ }^{24} 25$ Interleukin 1 is known to stimulate the acute phase protein response, and tumour necrosis factor/cachectin has several effects on fatty acid metabolism, such as decrease in the activity of lipoprotein lipase and inhibition of fatty acid synthesis. ${ }^{26}$ In addition, cytokines and eicosanoids are known to effect each other's liberation in several systems, ${ }^{27}$ which opens up even more possibilities of interactions which may exert an effect on the fatty acid composition in patients with RA. The possible effects of cytokines on fatty acid composition in different tissues need further investigation, however, before any more definite conclusions can be drawn as to their participation.

Another area of speculation is whether the changes observed in fatty acid composition may affect the immune system, and, if so, how. Many experimental studies have shown that intake of fat rich in linoleic acid markedly affects different aspects of immune function. ${ }^{27-29}$ Potentially beneficial effects have been observed in both essential fatty acid deficiency and surplus. ${ }^{27}$ In these studies the intake of fatty acids has often been extreme, and at present it is impossible to evaluate the effects on immune functions of the fairly modest differences in tissue fatty acid composition noted both by us and others. ${ }^{17} 18$ This is a field of inquiry also worthy of further study-for instance, in humans given commercially available lipid supplements with varying fatty acid composition.

A low value for 18:2 also seems to be an independent risk factor for coronary heart disease, ${ }^{1}$ and as mortality due to coronary heart disease may be higher among patients with $\mathrm{RA},{ }^{30}{ }^{31}$ the common denominator might well be a low concentration of 18:2.

Serum selenium concentrations have earlier been found to be low in patients with RA, both in adults ${ }^{32} 33$ and in juveniles, ${ }^{34}$ though whether the decrease is related to nutritional changes or inflammatory activity remains unclear. The main decrease occurs in a selenoprotein with an apparent molecular weight of $175 \mathrm{kD} .^{14}$

For the micronutrients in patients with RA others have found low values for ascorbic acid ${ }^{35}$ and retinol, ${ }^{36}$ and low or normal values for $\alpha$ tocopherol, folic acid, and cobalamine. ${ }^{37} 38$ The reason for these changes might well be inadequate dietary intake, though for the low ascorbic acid values both increased destruction by oxygen radicals from activated phagocytes ${ }^{39}$ and increased urinary excretion due to NSAIDs ${ }^{40}$ have been proposed as explanations. We found no significant decrease in the serum concentration of these micronutrients, though there was a non-significant tendency toward lower values for retinol and ascorbic acid among patients, a tendency which might have been significant in the case of ascorbic acid had the series been larger. The lower values for ascorbic acid, and the fact that its concentration correlated with those of the acute phase proteins, support the hypothesis that a correlation exists between the ascorbic acid concentration and the degree of inflammation.

The findings that women had higher values for mono-unsaturated fatty acids, and men higher values for saturated fatty acids in adipose tissue but not in serum phosphatidylcholine, are in accord with those of earlier investigations. ${ }^{8}$ 
Whether these sex differences reflect differences in dietary habits or differences in fatty acid metabolism is unknown. No significant sex differences were found for $18: 2$ and 18:3, or the longer chain fatty acids.

To sum up, we found that in patients with RA values for the essential fatty acids and selenium decreased with increased disease duration. At least for 18:2 in serum phosphatidylcholine the decrease seems to be related to the degree of inflammation, perhaps due to increased activity in the desaturase/elongation enzymes or to increased synthesis of eicosanoids.

Skilful assistance was given by Ms B Mattsson and Ms B Martensson. The study was supported by the Swedish Medical Research Council (grant No 3968), the Swedish Council for Planning and Coordination of Research (grant No A9-7-5), the Påhlsson Foundation, the Swedish Rheumatism Association, and the Simon and Margit Eliasson Trust.

1 Wood D A, Butler S, Macintyre C, et al. Linoleic and eicosapentaenoic acids in adipose tissue and platelets and risk of coronary heart disease. Lancet 1987; i: 177-83.

2 Vannoni D, Ciccoli L, Leoncini R, Marcolongo R, Marinello E. Fatty acid composition of plasma lipids in gout. Biomed Pharmacother 1986; 40: 348-51.

3 Horrobin D F. Essential fatty acid metabolism in diseases of connective tissue with special reference to scleroderma and to Sjögren's syndrome. Med Hypotheses 1984; 14: 233-47.

4 Johansson U, Portinsson S, Âkesson A, Svantesson H, Ákesson B. Fatty acid composition of plasma phosphatidylcholine and erythrocyte lipids, and dietary fat intake in juvenile chronic arthritis. Prog Lipid Res 1986; 25: 579-82.

5 Surge R A, Yates D B, Gordon D, et al. Prostaglandin production in arthritis. Ann Rheum Dis 1978; 37: 315-20.

6 Canonico P G, Rill W, Ayala F. Effects of inflammation on peroxisomal enzyme activities, catalase synthesis and lipid metabolism. Lab Invest 1977; 37: 479-86.

7 Kremer J M, Jubiz W, Michalek A, et al. Fish-oil fatty acid supplementation in active rheumatoid arthritis. Ann Intem Med 1987, $106: 497-503$.

8 Field C J, Clanidin M T. Modulation of adipose tissue fat composition by diet: a review. Nutrition Research $1984 ; 4$ : 743-55.

9 Dayton S, Hashimoto S, Dixon W, Pearce M L. Composition of lipids in human serum and adipose tissue during prolonged feeding of a diet high in unsaturated fat. $\mathcal{f}$ Lipid Res 1966; 76: 103-11.

10 Staveren W A, Deurenberg P, Katan M B, et al. Validity of the fatty acid composition of subcutaneous fat tissue microbiopsies as an estimate of the longterm average fatty microbiopsies as an estimate of the longterm average fatty Epidemiol 1986; 123: 455-63.

11 Field C J, Angel A, Clanidin M. Relationship of diet to the fatty acid composition of human adipose tissue structural and stored lipids. Am F Clin Nutr 1985; 42: 1206-20.

12 Ropes M W, Bennett G A, Cobb S, Jacox R, Jessar R A. Diagnostic criteria for rheumatoid arthritis. Ann Rheum Dis 1959; 18: 49-53.

13 Beynen A C, Katan M B. Rapid sampling and longterm storage of subcutaneous adipose tissue biopsies for determination of fatty acid composition. Am 7 Clin Nutr 1985; 42: $317-22$.

14 Borglund M, Åkesson A, Åkesson B. Distribution of selenium and glutathione peroxidase in plasma, compared in healthy subjects and rheumatoid arthritis patients. Scand in healthy subjects and rheumatoid

15 De Leenheer A P, De Bevere V O R C, De Ruyter M G M, Claeys A E. Simultaneous determination of retinol and $\alpha$ - tocopherol in human serum by high-pertormance liquid chromatography. F Chromatogr 1979; 162: 408-13.

16 Okamura $M$. An improved method for determination of L-ascorbic acid and L-dehydroascorbic acid in blood plasma. Clin Chim Acta 1980; 103: 259-68.

17 Bruderlein E, Daniel R, Boismenu D, Julien N, Couture F Fatty acid profiles of serum phospholipids in patients Fatty acid profiles of serum phospholipids in patients
suffering rheumatoid arthritis. Prog Lipid Res 1981; 20: sufferin

18 Haataja $\dot{M}$, Niemenen A L, Mäkisara D, Kalliomäki J L. Prostaglandin precursors in rheumatoid arthritis. f Rheumatol 1982; 9: 91-3.

19 Bigaouette J, Timchalk M A, Kremer J. Nutritional adequacy of diet and supplements in patients with rheumatoid arthritis who take medications. $\mathcal{f}$ Am Diet Assoc 1987; 87: 1687-8.

20 Portinsson S, Ákesson A, Svantesson H, Åkesson B. Dietary assessment in children with juvenile chronic arthritis. fournal of Human Nutrition and Dietetics 1988; 1 : 133-40.

21 Hagenfeldt $L$, Wennmalm $\AA$. Turnover of a prostaglandin precursor, arachidonic acid, in rheumatoid arthritis. Eur $\mathcal{f}$ precursor, arachidonic acid,

22 Brenner R. Nutritional and hormonal factors influencing desaturation of essential fatty acids. Prog Lipid Res 1982; 20: $41-8$.

23 Svensson K, Lundqvist G, Wide L, Hällgren R. Impaired glucose handling in active rheumatoid arthritis. I. Relationship to the secretion of insulin and counter-regulatory hormones. Metabolism 1987; 36: 944-8.

24 Duff G W, di Giovine F, Dickens E. Tumour necrosis factor and interleukin I in arthritis. Immunobiology 1987; 175: $10-11$.

25 Wood D D, Ihrie E J, Dinarello C A, Cohen P L. Isolation of an interleukin-1-like factor from human joint effusions. Arthritis Rheum 1983; 26: 975-83.

26 Patton J, Shepard M, Wilking $\mathrm{H}$, et al. Interferons and tumour necrosis factors have similar effects on 3T3 L tumour necrosis factors have similar effects on
cells. Proc Natl Acad Sci USA 1986; 83: 8313-7.

27 Hwang D. Essential fatty acids and immune response. Federation of American Societies for Experimental Biology fournal 1989; 3: 2052-61.

28 Ziff M. Diet in the treatment of rheumatoid arthritis. Arthritis Rheum 1983; 26: 457-61.

29 Thomas I K, Erickson K L. Fatty acid modulation of murine T-cell response in vivo. 7 Nutr 1985; 11: 1528-34.

30 Laakso M, Isomäki H, Mutru O, Koota K. Cardiovascular mortality in patients with rheumatoid arthritis. Scand $\mathcal{F}$ Rheumatol [S uppl] 1986; 59: 8 .

31 Prior P, Symmonds D P M, Scott D L, Brown R, Hawkins C F. Cause of death in rheumatoid arthritis. $B r \mathcal{F}$ Rheumatol 1984; 23: 92-9.

32 Aaseth J, Munthe E, Forre O, Steinnes E. Trace elements in serum and urine of patients with rheumatoid arthritis. Scand F Rheumatol 1978; 7: 237-40.

33 Tarp U, Overvad K, Hansen J C, Thorling E B. Low selenium level in severe rheumatoid arthritis. Scand $\mathcal{f}$ Rheumatol 1985; 14: 97-101.

34 Johansson U, Portinsson S, Åkesson A, Svantesson H, Öckerman P A, Ákesson B. Nutritional status in girls with juvenile rheumatoid arthritis. Hum Nutr Clin Nutr 1985; 40C: $57-67$.

35 Sahud $\mathbf{M ~ A , ~ C o h e n ~} \mathbf{R}$ J. Effects of aspirin ingestion on ascorbic acid levels in rheumatoid arthritis. Lancet 1971; $i$ : 937-8.

36 Me'zes M, Bartosiewicz G, Nemeth J. Comparative investigations on vitamin A level of plasma in some rheumatic diseases. Clin Rheumatol 1985; 5: 221-4.

37 Me'zes $M$, Bartosiewicz G. Investigations on vitamin $E$ and lipid peroxide status in rheumatic diseases. Clin Rheumatol 1983; 2: 259-63.

38 Robinson M D. Nutrition and rheumatic diseases. In: Kelley W N, Harris E D, Ruddy S, Sledge C D, eds. Textbook of rheumatology. Philadelphia: Saunders, 1980: 337-49.

39 Rowley D A, Halliwell B. Formation of hydroxyl radical from hydrogen peroxide and iron salts by superoxide- and ascorbate-dependent mechanisms: relevance to the ascorbate-dependent mechanisms: relevance to the

40 Johansson U. Ákesson B. Interaction between ascorbic acid and acetylsalicyclic acid and their effects on nutritional status in man. Int $\mathcal{J}$ Vitam Nutr Res 1985; 55: 197-204. 